\title{
Nuance of Meaning Synonym Transitive Verb Activities of See in Indonesia
}

\author{
Ranti Permatasari, Ngusman Abdul Manaf, Novia Juita \\ Universitas Negeri Padang \\ rantipermatasari.rp@gmail.com
}

\begin{abstract}
Several studies on synonyms have been done, but there are still unanswered questions. Previous research has only examined the same element of meaning between synonymous words, but not so much in the aspect of nuance of meaning. This article was written to explain the nuances of the synonym meaning of transitive verbs of activity of see in Indonesian. This type of research is qualitative by using descriptive method. The data of this research is Indonesian sentence which contains synonym of transitive verbs of activity of see in Indonesian. The source of this research data is national newspaper Padang Ekspress, Femina magazine, wedding invitation letter, and talk show of Mata Najwa in Metro TV 2017. Researcher acts as research instrument and assisted with tool in form of research for recording and analyzing data. Data collection techniques used in this study are document recording, tapping techniques, and introspection techniques. The results showed that all pairs of synonyms of transitive verbs of activity of see in Indonesian are nuanced meaning. Therefore, the synonym can only be replaced in a certain context.
\end{abstract}

Keywords-Indonesian; sense of meaning; synonyms; transitive verbs; activity of see

\section{INTRODUCTION}

Analysis of meaning in the field of synonyms has been widely practiced by language researchers, including (1) Taylor (2003) in New Zealand researching near synonyms as co-extensive categories; 'high' and 'tall' revisited, (2) Edmonds \& Hirst (2002) in Toronoto researchingnear synonymy and lexical choice, (3)Stanojevic (2009) in Serbia researching Cognitive synonymy: a general overview, (4) Utami (2010) in Surakarta researching study synonymous noun inIndonesian,(5) Ginanjar, Subroto, Sumarlam (2013) in Surakarta researching dimensions and components of meaning (+ACTION + HEAD + HUMAN), (6) Imelda (2013) in Medan researching analysis of the difference of meaning nuance of the word "toutou and yatto" in Japanese sentences, (7) Ariga (2013) in Sumatra North researching Use of Indonesian synonyms of kindergarten students TKIT Yaa Bunayya Southeast Aceh district through Upin and Ipin stories (television media): psycholinguistic studies, (8)Rahmatika (2013) in Semarang researching Synonyms nouns and adjectives dialect Banyumasan, (9) Suryatin (2014) in South Kalimantan researching the semantic analysis of verbs meaning of 'harm' in Banjar, (10) Danglli \& Abazaj (2014) in Italy researching units of synonymy and lexical relations, (11) Rahmati (2015) in Iran studied Semantic shifts, homonyms, synonyms and auto-antonyms, Junianto (2015) in Padang researchingnuances of meaning of verbs of hand activity in Indonesian, (12) Arifin (2015) Synonym in the Indonesian language, (13) Herlina (2016) in Surakarta researching variations and nuances of the meaning of verbs of Sanggau Malay, (14) Nandi (2016) in North Sumatra researching Phrase meaning of verb shikaru and okoru as a synonym, (15) Anggraini (2016) in Surakarta researching synonyms of human verbs in the Indonesian language. In general, the results of the study indicate that there is no synonym of absolute synonyms. In synonymous word pairs there are nuances of meaning.

The debate about synonyms is not a new thing for language observers. Some of themagree that synonyms are leksem that have the same meaning and can be used to replace their partners in all contexts (Hassan, 2014). However, some are opposed and argue that no two words actually have the same meaning (Stanojevic, 2009). They reject the idea of a complete and absolute synonym (Cruse, 2000; Stanojevic, 2009). According to him, different words require different meanings. Each word can give a certain meaning.

Some lexicographers claim that there are no synonyms that have exactly the same meaning (in all social contexts or levels of language), because there are several factors that make it different. Chaer (2009) describes the nuances of meaning including into one of the differentiating of the word bersinoim. Similarly, Edmonds \& Hirst (2002), explains that words that are close synonymous still have different meanings, although the difference is only in the nuances of meaning. Nuance of meaning is defined as the difference of meaning that is very smooth or thin between pairs of words that bersinonim (Puspitasari, 2013; Nandi, 2016).

The study of meaning is important to know (Danglli \& Abazaj, 2014). Meaning can serve as the representative of human thought and feeling (Arifin, 2015).

Based on the search results which as far as the authors do show that the nuances of synonyms meaning transitive verbs of sight activity have not given a thorough explanation. In fact, this study is considered important because it can add insight and knowledge for language users in communicating so that mistakes can be avoided. The purpose of this study was to explain the nuances of the synonym meaning of transitive verbs of visual activity in Indonesian. 


\section{METHODS}

Type of research is qualitative by using descriptive method. The data of this study are Indonesian sentences containing synonyms of transitive verbs of sight activity used in the standard range both orally and in writing used in official and unofficial situations. The source of this research data is national newspaper Padang Ekspress, magazine Femina, wedding invitation letter, and speech at talk show Mata Najwa on Metro TV. Researchers act as research instruments assisted with tools in the form of research that is useful for data collection and analysis. Data collection techniques of this study are document recording, tapping techniques, and techniques of introspection. Data analysis is done by identifying the cognitive and emotive meanings of each transitive verbal of the visual sense.

\section{FINDING AND DISCUSSION}

Transitional Synonym of Transitive Verbs of Activity of See in Indonesia

Test of synonymous transitive verbs of sight activity is performed by using two techniques, namely component component analysis, and substitution test.

Based on the result of data inventory, 10 pairs of transitive verbs of activity of see are allegedly synonymous. All of these transitive verbs are tested for their compatibility with component analysis techniques such as those exemplified in verbs viewing and monitoring as follows.

In Indonesian:

Tabel 1

Analisis Kesinoniman Verba Transitif Melihat dan Memantau Berdasarkan Analisis Komponen Makna

\begin{tabular}{cllcc}
\hline No & Komponen Makna & \multicolumn{2}{c}{ Pasangan Sinonim Verba Transitif } \\
\cline { 3 - 4 } & & melihat & memantau \\
\hline \multirow{2}{*}{ 1. } & Makna Kognitif & INDRA PENGLIHATAN & + & + \\
\cline { 2 - 4 } & & GERAK-GERIK SESUATU & + & + \\
\cline { 2 - 4 } & MENGUKUR SUATU & \pm & + \\
& PERKEMBANGAN & & + \\
\cline { 2 - 4 } & DENGAN TELITI & \pm & + \\
\cline { 2 - 4 } & ADA UNSUR MENGAWASI & + & + \\
\cline { 2 - 4 } & Makna Emotif & HALUS & + & + \\
\hline
\end{tabular}

Description:

+ component of meaning owned by

- component of meaning not possessed

In English:

\pm component of meaning which is owned or not owned

Table 1

Synonym of Syncynical Analysis of Transitive Verbs Look and Monitor Based on Component Analysis of Meaning

\begin{tabular}{|c|c|c|c|c|}
\hline \multirow[t]{2}{*}{ No } & & \multirow[t]{2}{*}{ Component of Meaning } & \multicolumn{2}{|c|}{ Pairs Transitive Verbs Synonym } \\
\hline & & & look & monitor \\
\hline \multirow[t]{6}{*}{1.} & Cognitive of & VISION INDRA & + & + \\
\hline & Meaning & SOMETHING MOVEMENTS & + & + \\
\hline & & MEASURING A DEVELOPMENT & \pm & + \\
\hline & & CAREFULLY & \pm & + \\
\hline & & $\begin{array}{l}\text { THERE ARE ELEMENTS OF } \\
\text { WATCHING }\end{array}$ & \pm & + \\
\hline & $\begin{array}{l}\text { Meaning of } \\
\text { Emotif }\end{array}$ & POLITE & + & + \\
\hline
\end{tabular}

Based on the meaning component in table 1, known pairs of verbs view and monitor are synonymous because most, that is $50 \%$ the element of meaning is the same. The same element of meaning is + INDRA PENGLIHATAN (VISION INDRA) , + GERAK-GERIK SESUATU (SOMETHING MOVEMENTS), and +HALUS (POLITE). Based on the results of the synonymous test on elements of that meaning component, the transitive verb melihat and memantau are synonymous.

A pair of transitive verbs that were proven to be synonymous based on component component analysis test then performed a second synonym test, namely substitution test. If a word in any context can be mutually reinforcing and the word meaning in the kotex is relatively the same, then the two words are synonymous (Djadjasudarma, 1993). All 
transitive verb pairs of sight activity are tested for their synonyms by using substitution tests as exemplified inverbs melihat and memantau as follows.

In Indonesian:

(1) Pemburu sedang melihat target buruannya.

(2) Pemburu sedang memantau target buruannya.

In English:

(1) The hunter is looking at his target target.

(2) The hunter is monitoring the target of the hunt.

Transitive verb pairs melihat and memantau in sentences (1) and (2) are known to replace each other in a certain context and their meaning is relatively similar. Based on the results of the substitution test, the transitive verbs melihat and memantau are synonymous.

Based on the test results of synonymous transitive verb of activity of see by using the component analysis test of meaning and substitution test as exemplified, the synonym pair obtained as listed in table 3 .

In Indonesian:

Table 2

Pasangan Sinonim Verba Transitif Aktivitas Melihat Berdasarkan Hasil Uji Analisis Komponen Makna dan Uji Subtitusi

\begin{tabular}{|c|c|c|c|}
\hline \multirow[t]{2}{*}{ No } & \multicolumn{2}{|c|}{ Pasangan Sinonim Verba Transitif } & \multirow[t]{2}{*}{ Persamaan Makna } \\
\hline & $\mathrm{A}$ & $\mathrm{B}$ & \\
\hline 1 & melihat & memantau & 'mengawasi sesuatu atau gerak gerik dengan nilai rasa halus'. \\
\hline 2 & melihat & memperhatikan & 'mengawasi sesuatu atau gerak-gerik dengan nilai rasa halus'. \\
\hline 3 & melihat & menatap & 'memandang sesuatu hal/benda/insan'. \\
\hline 4 & melihat & mengamati & 'mengawasi sesuatu dengan nilai rasa halus'. \\
\hline 5 & memantau & memperhatikan & $\begin{array}{l}\text { 'mengawasi sesuatu atau gerak gerik secara teliti dan seksama } \\
\text { dengan nilai rasa halus'. }\end{array}$ \\
\hline 6 & memantau & menatap & 'memandang sesuatu secara lama dengan nilai rasa halus'. \\
\hline 7 & memantau & mengamati & $\begin{array}{l}\text { 'mengawasi sesuatu secara teliti dan lama dengan nilai rasa } \\
\text { halus'. }\end{array}$ \\
\hline 8 & memperhatikan & menatap & 'memandang sesuatu dengan nilai rasa halus'. \\
\hline 9 & memperhatikan & mengamati & 'memandang sesuatu dengan nilai rasa halus'. \\
\hline 10 & menatap & mengamati & $\begin{array}{l}\text { 'memandang sesuatu dalam waktu yang tidak sebentar dengan } \\
\text { nilai rasa halus'. }\end{array}$ \\
\hline
\end{tabular}


In English:

Table 2

Pairs Synonyms Verb Transitive of Activity of See

Based on Test Results Component Analysis and Substitution Test

\begin{tabular}{clll}
\hline \multirow{2}{*}{ No } & \multicolumn{2}{c}{ Pairs Synonyms Verb Transitive } & \\
\cline { 2 - 3 } & \multicolumn{2}{c}{ A } & \multicolumn{2}{c}{ B } & Equation Meaning \\
\hline 1 & look & monitor & 'keep an eye on things or move with subtle taste values'. \\
\hline 2 & look & pay attention & 'keep an eye on things or gestures with subtle taste values'. \\
\hline 3 & look & stare & 'looking at things / things / people'. \\
\hline 4 & look & observe & 'keep an eye on things with a subtle taste value'. \\
\hline 5 & monitor & pay attention & $\begin{array}{l}\text { 'supervise something or move carefully and carefully with the } \\
\text { value of smooth taste'. }\end{array}$ \\
\hline 6 & monitor & starte & 'look at things for a long time with a subtle value'. \\
& monitor & observe & 'keep an eye on things carefully and for a long time with \\
subtle taste values'.
\end{tabular}

Nuance of Meaning of Synonym of Transitive Verbs of Activity of See in Indonesian

In this study, the analysis of meaning nuances is done by comparing the elements of cognitive meaning, emotive meaning element, and the ability of synonymous couples of transitive verbs of activity of see to be interchangeable in one context. All transitive verb pairs of activity of see are determined by their meaning-based meaning component analysis as exemplified in the synonymous pair of transitive verbs melihat and menatap as follows.

In Indonesian:

Table 3

Analisis Komponen Makna Pasangan Sinonim Verba Transitif Melihat dan Menatap

\begin{tabular}{|c|c|c|c|c|}
\hline \multirow[t]{2}{*}{ No } & \multicolumn{2}{|c|}{ Komponen Makna } & \multicolumn{2}{|c|}{ Pasangan Sinonim Verba Transitif } \\
\hline & & & melihat & menatap \\
\hline \multirow[t]{5}{*}{2.} & Makna Kognitif & INDRA PENGLIHATAN & + & + \\
\hline & & $\begin{array}{l}\text { ADA UNSUR } \\
\text { MENGAWASI }\end{array}$ & + & + \\
\hline & & SECARA LAMA & \pm & + \\
\hline & & $\begin{array}{l}\text { MENGUKUR SUATU } \\
\text { PERKEMBANGAN }\end{array}$ & \pm & - \\
\hline & Makna Emotif & HALUS & + & - \\
\hline
\end{tabular}

In English:

Table 3

Component Analysis Transitive Verb Meaning Couple look and stare

\begin{tabular}{cllcc}
\hline \multirow{2}{*}{ No } & \multicolumn{2}{c}{ Component of Meaning } & \multicolumn{2}{c}{ Pairs Transitive Verbs Synonym } \\
\cline { 3 - 4 } & & look & stare \\
\hline \multirow{2}{*}{$\begin{array}{l}\text { Cognitive Meaning } \\
\text { of }\end{array}$} & \multicolumn{2}{c}{ VISION INDRA } & + & + \\
\cline { 2 - 4 } & & THERE ARE ELEMENTS OF & + & + \\
& & & + \\
\cline { 2 - 4 } & WATCHING & \pm & - \\
\cline { 2 - 4 } & FOR A LONG TIME & + & + \\
\cline { 2 - 4 } & MEASURING A & + & + \\
\hline
\end{tabular}


On the table 5, it is known that there is a difference in the meaning component, that is, there are three differences from the five elements of meaning that are compared. Verbs melihat has a component of meaning \pm MENGUKUR SUATU PERKEMBANGAN meaning can be used to express an action performed by the sense of sight to measure a development that is being seen while the verb menatap does not have that component of meaning. Verbs menatap has the meaning component + SECARA LAMA it is means, it can be used to declare the act of seeing something in a long duration of time while verbs melihat can be used to declare the action and can also not. Then,verbs melihat have a mean component + HALUS means the verbs melihat worthy of subtle flavors while the verb menatapat the not so subtle (coarse) taste. Verbs melihat and menatap not only nuanced meanings on cognitive meaning but also have a sense of meaning in the grammatical context, ie can not replace each other in a particular context. Nuances of the meaning of transitive verb pair of sight activity in synonymous pairs melihat and menatap at the grammatical context can be seen in sentences (3) and (4).

(3) Saat duduk di warung, secara tidak sengaja aku melihat pengendara motor yang memacu kendaraannya dengan kencang.

(4) *Saat duduk di warung, secara tidak sengaja aku menatap pengendara motor yang memacu kendaraannya dengan kencang.

Verbs menatap can not be used in koteks sentence saat duduk di warung, secara tidak sengaja aku ... pengendara motor yang memacu kendaraannya dengan kencang as in the example of sentence (4). Instead,verbs melihat can be used in contexts sentence saat duduk di warung, secara tidak sengaja aku ... pengendara motor yang memacu kendaraannya dengan kencang as in the example sentence (3). Based on the results of the component analysis of meaning and substitution, the synonym of transitive verbs melihat and menatap is nuanced meaning.

Based on the results of component analysis of the meaning of 10 pairs of transitive verb synonyms, visual activity in the Indonesian language shows the result that all pairs of synonyms transitive verbs are nuanced meaning as written in the following table 4 .

In Indonesian:

Table 4

Nuansa Makna Pasangan Sinonim Verba Transitif Aktivitas Melihat Berdasarkan Analisis Komponen Makna

\begin{tabular}{|c|c|c|c|c|}
\hline \multirow[t]{2}{*}{ No } & \multicolumn{4}{|c|}{ Nuansa Makna Pasangan Sinonim Verba Transitif Aktivitas Melihat dalam Bahasa Indonesia } \\
\hline & A & Makna & $\mathrm{B}$ & Makna \\
\hline 1 & melihat & 'bersifat umum' & memantau & 'bersifat khusus' \\
\hline 2 & melihat & 'secara sekilas' & memperhatikan & 'secara seksama' \\
\hline 3 & melihat & 'secara sebentar' & menatap & 'secara lama' \\
\hline 4 & melihat & 'secara sekilas' & mengamati & 'secara teliti' \\
\hline 5 & memantau & 'terkandung nilai rasa halus' & memperhatikan & 'memiliki nilai rasa kasar' \\
\hline 6 & memantau & 'secara lama dan teliti' & menatap & 'secara lama' \\
\hline 7 & memantau & 'dari jauh' & mengamati & 'dari jauh atau dekat' \\
\hline 8 & memperhatikan & $\begin{array}{l}\text { 'ada unsur mengawasi dan } \\
\text { secara diam-diam' }\end{array}$ & menatap & 'secara langsung' \\
\hline 9 & memperhatikan & $\begin{array}{l}\text { 'ada unsur mengawasi dan } \\
\text { secara diam-diam' }\end{array}$ & mengamati & $\begin{array}{l}\text { 'ada unsur mengawasi dan } \\
\text { secara terang-terangan' }\end{array}$ \\
\hline 10 & menatap & 'dari dekat' & mengamati & 'dari jauh dan dekat' \\
\hline
\end{tabular}


In English:

Table 4

Nuances Meaning of Coupons Synonyms Transitive Verb of Activity of See

Pursuant to Component Analysis Meaning

\begin{tabular}{|c|c|c|c|c|}
\hline \multirow[t]{2}{*}{ No } & \multicolumn{4}{|c|}{ Nuance Meaning of TransitiveVerb of Activity of See in Indonesia } \\
\hline & $\mathrm{A}$ & Meaning & $\bar{B}$ & Meaning \\
\hline 1 & look & 'General nature' & monitor & 'Special' \\
\hline 2 & look & 'At a glance' & pay attention & 'carefully' \\
\hline 3 & look & 'Briefly' & stare & 'Long time' \\
\hline 4 & look & 'At a glance' & observe & 'Carefully' \\
\hline 5 & monitor & $\begin{array}{l}\text { 'Contained the value of } \\
\text { delicate taste' }\end{array}$ & pay attention & $\begin{array}{l}\text { 'Contained a sense of } \\
\text { coarse value' }\end{array}$ \\
\hline 6 & monitor & 'Long and careful' & stare & 'With a long time' \\
\hline 7 & monitor & 'from afar' & observe & 'From far or near' \\
\hline 8 & pay attention & $\begin{array}{l}\text { 'There is an element of } \\
\text { watching and secretly' }\end{array}$ & stare & 'directly' \\
\hline 9 & pay attention & $\begin{array}{l}\text { 'There is an element of } \\
\text { watching and secretly' }\end{array}$ & observe & $\begin{array}{l}\text { 'There is an element of } \\
\text { supervising and openly' }\end{array}$ \\
\hline 10 & stare & 'Up close' & observe & 'From far and near' \\
\hline
\end{tabular}

The results of this study indicate that all couples transitive verb synonym visual activity of see are nuanced meaning. Thus, no synonym pair is found that has the same element of meaning perfectly. The results of this study are in line with the results of research conducted by Utami (2010) researching of synonim noun in Indonesian, Imelda (2013) researching nuance of meaning analysis of words toutou and yatto in Japanese sentences, Junianto (2015) nuances of meaning of the verb of hand activity in Indonesian, and Permatasari (2018) researching nuances of meaning transitive verb synonym in affixes meN-i in Indonesian.

The novelty of the results of this study is compared with the results of previous research, namely Utami (2010), Imelda (2013), and Junianto (2015). The results of this study indicate that the sense of the synonym pair of transitive verbs of activity of see is the difference of the elements of cognitive meaning. The relevant research results do not explain the determinants of the nuances of meaning.

\section{CONCLUSION}

Based on the results of research on the synonym of transitive verbs of visual activity in Indonesian language, obtained two conclusions as follows. First, there are 10 pairs of transitive verbs of activities if see wich are proven to be synonymous based on the concurrence test. This is because there are similarities in the meaning elements of more than $50 \%$ and have the ability to be able to replace each other in the same sentence. Second, all pairs of synonyms of transitive verbs of sight activity are nuanced in meaning. Thus, the synonym of transitive verbs of sight activity can be mutually replaced only in the context of a particular sentence. This requires awareness and carefulness for language users when using synonyms when communicating. The results of this study can be utilized for the improvement of the Indonesian synonym dictionary .

\section{References}

Ariga, H. P. S. (2013). Penggunaan sinonim bahasa Indonesia siswa taman kanak-kanak tkit yaa bunayya kabupaten Aceh Tenggara melalui cerita Upin dan Ipin (media televisi): kajian psikolinguistik. Kajian Linguistik, 10(2), 231-245.

Anggraini. (2016). Afiksasi pembentukan verba dalam teks berita siswa kelas vii di smp darul muttaqien Jakarta tahun pelajaran 2013/2014. (Skripsi, Universitas Islam Negeri, 2016).

Arifin, E. Z. (2015). Kesinoniman dalam bahasa Indonesia. Pujangga, 1(1), 1-13.

Chaer, A. (2009). Pengantar semantik bahasa Indonesia. Jakarta: Rineka Cipta.

Cruse, D. A. (2000). Meaning in language: an introduction to semanticsand pragmatics. Cambridge: Cambridge University Press

Danglli, L. (2014). Units of synonymy and lexical relations. Mediterranean Journal of Social Sciences, 5(13), $522-525$.

Danglli, L. \& Abazaj, G. (2014). Lexical cohesion, word choice and synonymy in academic writing. Mediterranean journal of social sciences, 5(14), 628-632. 
Djajasudarma, F. (1993). Semantik 1 pengantar ke arah ilmu makna. Jakarta: ERESCO.

Edmonds, P \& Hirst, G. (2002). Near synonymy and lexical choice. Compulational Linguistics, 28(2), 105-144.

Ginanjar, B., Subroto, D. E.\& Sumarlam. (2013). Dimensi dan komponen makna medan leksikal verba bahasa indonesia yang berciri (+tindakan +kepala +manusia). Transling journal: translation and linguistics, 1(1) 65-75.

Hassan, A. E. (2014). Readdressing the translation of near synonymy in the glorious qur'an. European Scientific Journal, 10(8), 165-191.

Herlina, H. (2016). Variasi dan nuansa makna verba melayu sanggau Kalimantan Barat. Prosiding PRASASTI, 386-390.

Imelda. (2013). Analisis perbedaan nuansa makna kata toutou dan yatto dalam kalimat bahasa Jepang. (Skripsi, Universitas Sumatera Utara, 2013).

Junianto. (2015). Nuansa makna verba aktivitas tangan dalam bahasa Indonesia. (Tesis, Universitas Negeri Padang, 2015).

Nandi. (2016). Ungkapan makna verba shikaru dan okoru sebagai sinonim. Jurnal Bahasa FBS-UNIMED. 110-118.

Permatasari, R. Manaf, N. A., \& Juita, N. (2018). Nuances of meaning transitive verb synonym in affixes meN-i in Indonesian. Prosiding Seminar International Conferences on Educational, Social Sciences and Technology: 353360. Padang, 14-15: Fakultas Ilmu Pendidikan.

Puspitasari. L. (2013). Sinonim antonim dan padanan kata. Jakarta: Infra Pustaka.

Rahmati, F. (2015). Semantic shift, homonyms, synonyms and auto-antonyms. WALIA journal, 31(S3), 81-85.

Rahmatika, E. (2013). Sinonim nomina dan adjektiva dialek Banyumasan. (Skripsi, Universitas Negeri Semarang, 2013).

Stanojevic, M. (2009). Cognitive synonymy: a general overview. Linguistics and Literature, 7(2), 193-200.

Suryatin, E. (2014). Analisis semantik verba bermakna 'menyakiti' dalam bahasa Banjar. Metalingua, 2(1), 43-56.

Taylor, J., R. (2003). Near synonyms as co-extensive categories: 'high' and 'tall' revisited. Language Sciences, 25(3), 263-284.

Utami, R. (2010). Kajian sinonim nomina dalam bahasa Indonesia. Tesis, (Universitas Sebelas Maret, 2010). 